Article

\title{
Welfare Chauvinism, Economic Insecurity and the Asylum Seeker "Crisis"
}

\author{
Boris Heizmann *, Alexander Jedinger $\left(-\right.$ and Anja Perry ${ }^{(1)}$ \\ GESIS-Leibniz Institute for the Social Sciences, Unter Sachsenhausen 6-8, 50667 Cologne, Germany; \\ alexander.jedinger@gesis.org (A.J.); anja.perry@gesis.org (A.P.) \\ * Correspondence: boris.heizmann@gesis.org
}

Received: 15 June 2018; Accepted: 29 August 2018; Published: 10 September 2018

\begin{abstract}
Immigration has been a major trend in the last decades in Europe. However, immigrant access to the social security systems has remained a contentious issue having gained additional salience in light of the recent asylum-seeking developments. We focus on welfare chauvinism, the idea that immigrants should not participate in welfare resources, as an attitudinal dimension. We seek to answer two primary questions: To what extent are different types of objective and subjective material deprivation related to welfare chauvinism? What is the role of the recent asylum seeker influx? Using European Social Survey data and employing binary and generalized ordered logit models with country fixed effects, we find perceptions of deprivation to be more meaningful than objective factors related to potential job loss, and some relationships depend on the specific type of deprivation. On the country level, in line with the deservingness of asylum seekers as a group, higher levels of asylum seeking are related to lower levels of welfare chauvinism, while GDP per capita is not associated with welfare chauvinism. Finally, the generalized ordered logit model shows that some relationships vary according to the strictness of welfare chauvinism, which would not be visible in a conventional ordered logit model.
\end{abstract}

Keywords: immigration; welfare chauvinism; public opinion; European Social Survey; Europe

\section{Introduction}

Although the ebbs and flows of international migration have become a permanent phenomenon [1], immigration is often viewed as a surging burden for a variety of institutions, most prominently the welfare state. Welfare state resources are a major publicly funded good and usually a prerogative of national citizens, although non-citizens cannot be fully excluded from access to these resources [2-4]. However, despite an overall trend towards more inclusive incorporation policies [5-7], immigrant access to these resources remains a contested issue. Welfare chauvinism, the belief that the welfare state should be responsible only for its own citizens, has therefore received increased attention in recent years [8-13], and we will investigate public opinion on this issue.

We seek to address several issues in this article, and our two research questions are located on the micro and the macro level, respectively. One is that we want to gain a better understanding of the micro-level foundations of welfare chauvinism. What is the role and relative importance of objective and subjective types of (potential) material deprivation and insecurity? This line of inquiry addresses the fact that individuals differ in their propensity to become welfare state recipients or net-financers. These issues thus should not only shape individual outlook on the welfare state in general, but also the perceived competition for such resources that strongly underlies chauvinistic attitudes. Second, given the recent asylum seeker influx to Europe, which some deem to be a crisis that poses a potentially strong burden on government and welfare state resources, we ask whether this specific type of immigration has led to a more restrictive stance towards immigrant welfare, 
or-assuming an overall deservingness of the "median" asylum seeker-to a less restrictive, i.e., more generous view on the topic.

\section{Welfare Chauvinism: Theory and State of the Art}

Immigration poses a central problem to nation states in general and the welfare state in particular [3,4,14,15]: How should a state and its institutions approach those who are not citizens, i.e., not members of the defined imagined community, but who are by way of "denizenship" [16], of permanently residing in the country, entitled to at least some rights? This tension not only occupies sociologists, political scientists and political economists minds, but it also leads to a diverse range of public opinion regarding this issue. Welfare chauvinism [17] represents one end of the spectrum and simultaneously the label usually assigned for a more restrictionist view: Welfare state access should remain in the hands of the native citizen population, in the extreme definition restricted to persons not only having the citizenship of said nation state, but also having further ancestry within that state.

Welfare chauvinism emerged as a field of inquiry at the intersection between social policy research, voting behavior and research on attitudes towards immigration. Originally, the concept was introduced to make sense of the growing electoral success of right-wing populist parties in Europe who combine anti-immigration stances with pro-welfare policies [17,18]. Kitschelt and McGann [17] define welfare chauvinism as the view that "the welfare state $[.$. ] is a system of social protection for those who belong to the ethnically defined community and who have contributed to it" (p. 22). A core assumption underlying welfare chauvinism is the belief that immigrants are "free-riders" who receive social benefits without having contributed adequately to this publicly funded club good. The tendency to differentiate social rights according to nationality and ethnicity has been demonstrated in several survey experiments [11,12,19]. A closer look, however, reveals that welfare preferences regarding non-natives are more complex and should be more appropriately viewed as a continuum that ranges from (unconditional) inclusion to total exclusion $[13,20]$. At the one end, we find the position that immigrants should have unrestricted access to welfare benefit schemes. Another position conditions social benefits on previous contributions to the welfare system, which typically means working and paying taxes. A third position draws the line between legitimate and illegitimate welfare beneficiaries on the basis of citizenship. Finally, at the extreme end of the continuum, access to the welfare systems is restricted to members of the ethnic in-group. This concept can thus be related to other types of exclusionary policy preferences, such as immigration policy attitudes [9,21-23].

Past research indicates that most Europeans are in favor of allocating social benefits on the basis of reciprocity [13,20]. For instance, using the fourth wave of the European Social Survey 2008/2009, Mewes and Mau [20] found that most respondents favor conditional access to welfare services based on work and tax payments (41\%) or acquiring citizenship (35\%). Only $16 \%$ think that welfare benefits should be granted unconditionally to immigrants. Pure forms of welfare chauvinism, on the other hand, can only be found in a minority, as only a small share (9\%) adheres to the view that welfare benefits should be available exclusively to co-ethnics. However, there are also large national differences. Inclusionist views are most often found in Denmark, Norway Sweden and Switzerland. By contrast, support for a complete exclusion is highest in Cyprus, Greece, Latvia and the Czech Republic.

Attempts to explain why people hold various degrees of welfare chauvinistic attitudes have largely drawn on realistic group conflict [24-26] and ethnic competition theory [27]. According to these theories, conflicts between natives and immigrants arise from actual or even perceived competition for scarce and valuable resources such as jobs, affordable housing and transfer payments. Distributional conflicts are perceived as zero-sum games in which one group wins at the expense of another group. This is reflected in a preference for the exclusion of immigrants from the welfare system. A central implication of the theory is that those who hold socio-economic positions similar to those of immigrants feel most threatened because they compete for the same material resources [28]. Because immigrants tend to be less well educated and disproportionately dependent on transfer payments, natives with a lower socioeconomic status are more likely to adopt welfare chauvinistic 
attitudes. Consistent with the competition hypothesis, past research has demonstrated that strict forms of welfare chauvinism are closely related to low education, income, occupational status and perceived economic insecurity $[11,13,20]$.

However, such factors have not often been tested against one another in a way that distinguishes objective and subjective factors more extensively. Here we intend to contribute to the literature by asking whether the subjective dimension of material insecurity can be compounded with objective measures of actual job insecurity. In doing so, we draw on the Job Polarization theory and measure actual job insecurity by the share of routine tasks at the job. Deviating from the "Skill-Biased Technological Change" hypothesis (see for example Acemoglu and Autor [29] for an overview), the Job Polarization Theory describes the recent phenomenon that demand for middling occupations decreases while demand for low- and high-skilled and -earnings occupations remains steady or even increases. These trends have been described for the United States [30-32], the United Kingdom [33], Germany [34,35] and for 16 Western European countries [36]. The reason behind this trend is that recent technological change replaces labour in routine tasks. Goos, Manning and Salomons [36] therefore call it Routine-Biased Technological Change (RBTC). These routine tasks are mainly found in the middle of the skill and earnings distributions, for example machine operators or office clerks. Their tasks can increasingly be replaced by machines. As a result, employment and earnings in these occupations decrease. At the lower end of the distributions (in terms of education and earnings) are service occupations, such as food service workers, security guards, cleaners, hairdressers, and beauticians. Their tasks involve mainly non-routine tasks which cannot easily be replaced by machines. Thus, their share of US labour hours increased by 30\% between 1980 and 2005 [30]. At the upper end, managers, engineers, mathematicians, and other professionals perform high-skilled, abstract tasks, which are also not easily replaced by machines. Also, for these occupations the previous literature documents an increase in demand $[30,36]$. Hence, demand for occupations with high shares of routine tasks decreases, implying objective job insecurity for workers in these occupations, which in turn should translate into higher levels of welfare chauvinism.

In addition to objective job-related insecurity, being a benefactor or beneficiary of the welfare state is one aspect that we will consider in the analyses below. Given the competition-related nature of welfare chauvinism, the basic, self-interest-related assumption is that the individual outlook regarding the welfare state should be of key relevance. We will therefore distinguish between individuals who are in paid work, are unemployed, or are retired.

A final individual-level aspect lies in different forms of general current and prospective deprivations. Current economic hardships over and above the issue of labour market integration have seldom been put forward as determinants of welfare chauvinism, but perceived material risk was found to be related to welfare chauvinism e.g., Mewes and Mau [e.g. 10]. However, distinguishing the economic situation from labour market status as such is important in order to disentangle the potential influence of material deprivation, the individual role in the generation of welfare state resources, and occupation-based objective insecurity as outlined above. Labour market status and general deprivation thus should play a notable role, but the literature so far has not provided a differentiated assessment of the different factors that may be at play here.

In sum, our focal hypotheses on the individual level are:

Hypothesis 1 (H1). Objective job insecurity is associated with higher welfare chauvinism.

Hypothesis 2 (H2). Perceived income deprivation is associated with higher welfare chauvinism.

Hypothesis 3 (H3). Expected future income problems are associated with higher welfare chauvinism.

Hypothesis 4 (H4). Expected future employment problems are associated with higher welfare chauvinism. 
On the country level, worsening economic conditions have been shown to fuel support for the exclusion of immigrants from the welfare system, while the unemployment level and the size of the immigrant population seems to be unrelated to welfare chauvinism $[10,13,20,37,38]$. Furthermore, higher social expenditures $[13,20]$ and social-democratic welfare regimes are associated with less restrictive views on immigrant's welfare rights [37].

Although we are aware of the complexities of the aforementioned social policy aspects and the extant conceptualizations and empirical operationalizations applied in attitude research [39-43], we do not seek to provide a panorama across several aspects of social policy cf. Van Der Waal et al. [37] for an example of such an investigation. We rather want to remove the background influence from any factors related to socioeconomic and expenditure cycles by using a measure that is broad and broadly available across the countries investigated. Therefore, GDP per capita serves as a primary control variable depicting economic circumstances within the countries. This also prevents potential overfitting on the country level, especially since we are interested in the potential influence of asylum seeker influx in a more dynamic within-country setting using a fixed effects approach. Moreover, since many of these factors are interrelated, for example GDP per capita and social expenditure, we will account only for the former as a control variable in order to capture broad socioeconomic dynamics within the countries.

On this analytical level we will exploit the fact that the data we use enables us to investigate changes in welfare chauvinism between 2008/09 and 2016/17, which allows assessment of whether the current asylum seeker influx in Europe plays a role. For such a relationship, two divergent accounts can be formulated. First, in line with the competition-based accounts outlined above, asylum seeker presence can reduce the willingness to include immigrants in the welfare state: That is, asylum seekers can be seen to compete with natives when it comes to welfare state resources, since hosting a large number of asylum seekers incurs costs that burden the respective state's budget. This suggests that a higher presence of asylum seekers entails a welfare chauvinist backlash. This is also in line with more general, competition-based theorizing of the influence of outgroup presence on animosity towards that group $[24,25,44]$. However, given the outcome we are dealing with, this reasoning can be compounded with insights from the literature on deservingness, i.e., the question of who may legitimately access welfare state resources. A factor that has been identified as a primary indicator of deservingness of an individual or group is whether neediness is of their locus of control [8], and there is evidence that the mechanism behind this is based on an automatic psychological heuristic, rather than on political values [45]. Since asylum seekers may be seen, on average, as less able to influence the situation in their home countries, their presence may not be seen as an undue burden to the welfare state, instead leading to lower levels of welfare chauvinism due to humanitarian concern for them [46,47]. Moreover, refugee migration often disrupts family ties, which also influences perceived deservingness [12]. Thus, while immigrants were found to be the group viewed as least deserving across Europe [8,48], the present asylum seeker presence may stimulate readiness to extend welfare support to immigrants in general because it makes this more deserving subgroup of immigrants salient. Again, turning to the literature on anti-immigrant attitudes, these arguments can be complemented with the contact hypothesis: In contrast to approaches based on ethnic competition, it is argued that prolonged experience of immigrants and immigration can lead to more tolerance [49-51], thus also suggesting that asylum seeker presence leads to more benevolent attitudes.

In sum, the literature so far has put limited emphasis on the issues outlined above, as a more extensive investigation of different types of deprivation and expectations has, to our knowledge, not been undertaken yet. On the macro level, our contribution aims at addressing to what extent the recent asylum-seeking developments in Europe have a bearing on welfare chauvinism, net of GDP per capita developments. Given the theoretical approaches mentioned above, this contentious issue has a potentially strong influence, but whether this stimulates inclusive or exclusive notions of immigrant welfare access is far from evident.

Taken together, these arguments suggest the following hypotheses: 
Hypothesis $\mathbf{5}$ (H5). A higher GDP is associated with lower welfare chauvinism.

Hypothesis 6a (H6a). A higher asylum seeker influx is associated with higher welfare chauvinism.

Hypothesis $\mathbf{6 b} \mathbf{( H 6 b ) . ~ A ~ h i g h e r ~ a s y l u m ~ s e e k e r ~ i n f l u x ~ i s ~ a s s o c i a t e d ~ w i t h ~ l o w e r ~ w e l f a r e ~ c h a u v i n i s m . ~}$

\section{Materials and Methods}

The data we use come from the fourth ${ }^{1}$ and eighth ${ }^{2}$ round of the European Social Survey, fielded in 2008/09 and 2016/17. Both rounds include a module on "Welfare attitudes" which includes the following indicator of welfare chauvinism (Table 1):

Table 1. Welfare Chauvinism Indicator (ESS).

Q. Thinking of people coming to live in [country] from other countries, when do you think they should obtain the same rights to social benefits and services as citizens already living here? Please choose the option on this card that comes closest to your view.

(1) Immediately on arrival

(2) After a year, whether or not they have worked

(3) After they have worked and paid taxes for at least a year

(4) Once they have become a citizen

(5) They should never get the same rights

Source. European Social Survey. The dashed line shows the cut-off for the binary version of the variable and was not displayed on the card shown to the respondent.

As is evident, the outcome variable can be seen to be ordinal, although it has not always been treated as such in the literature due to category 4 having a potentially ambiguous relationship to categories 1-3 [37]. However, given what we know about the regulations and individual-level processes surrounding citizenship acquisition [52-55], we can judge naturalization to be-by and large-a more difficult hurdle than working and paying taxes for a year. This is even more so since the item explicitly refers to "people coming to live in [country] from other countries", i.e., first-generation immigrants for whom jus soli citizenship cannot normally apply. At the same time, it is obvious that this outcome variable does not cover all potential approaches to granting immigrants welfare access. For example, neither a restriction to certain types of immigrants, nor a restriction to certain types of welfare resources is envisaged in the questionnaire item. As noted above, the broadness of such a measure has not inhibited research into this topic, but we need to be aware of the fact that the actual policy implementation of immigrant welfare access is a much more complex issue than this indicator might suggest.

In the first step, we will perform multilevel binary logit analyses [56] on a dichotomized version of the variable, grouping the "Once they have become a citizen" and "They should never get the same rights" categories as " 1 " and the more inclusive categories as " 0 ". The reason for this grouping is, apart from the assertions made above, that the reference to citizenship implies a certain minimum of welfare generosity towards immigrants that may appear difficult to be abolished, given the fundamental importance of citizenship for social rights [3]. Our binary logit models consist of individuals nested in country-years, and we add country dummies as fixed effects into the models.

In any event, in contrast to conventional Likert scale ratings, the steps between categories are of quite varying width and substantive meaning. Put differently, strongly divergent policy options

1 ESS Round 4: European Social Survey Round 4 Data (2008). Data file edition 4.4. NSD—Norwegian Centre for Research Data, Norway-Data Archive and distributor of ESS data for ESS ERIC.

2 ESS Round 8: European Social Survey Round 8 Data (2016). Data file edition 2.0. NSD—Norwegian Centre for Research Data, Norway—Data Archive and distributor of ESS data for ESS ERIC. 
superimpose the underlying, gradual concept of welfare chauvinism, even though they are sorted along increasing exclusivity. The proportional odds assumption of conventional ordered logit analysis-equal effects across all levels of the dependent variable - therefore appears to be in question: The feasibility of these policies may be of a different rank order than that of the restrictiveness of the policy. For these reasons we will perform a generalized ordered logit analysis with cluster-robust standard errors in a second step. This allows effects to vary from level to level while facilitating a more straightforward interpretation of the results than a multinomial logit offers $[57,58]$. Because answering this question with category 5 "They should never get the same rights" was highly uncommon in some countries, we recode those cases to the value 4 . Therefore, the generalized ordered model will result in three equations with different cut-offs of the four-level-dependent variable described above. These three equations refer to increasingly strict forms of welfare chauvinism: Categories 2, 3 and 4 vs. category 1 , categories 3 and 4 vs. categories 1 and 2, and category 4 vs. categories 1, 2 and 3 . For this analytical step we will need only one model so that interpreting the raw coefficients is feasible [59].

Table 2 presents an overview of the variables used in the analyses. Our primary indicators on the individual level refer to perceptions and experiences of material deprivation. In contrast to the previous literature, we distinguish in more detailed fashion between experienced material deprivation, expectations of material deprivation, and objective threats in the form of experience in a highly standardized occupational environment that could feasibly be substituted with technology. The latter is measured via the RTI index which is defined as the amount of routine tasks minus the amount of abstract and (non-routine) manual tasks, within each occupation as defined by the ISCO08 classification available in the European Social Survey. Control variables are age, gender, whether the respondent is born in the country, education, and left-right self-placement. The variance inflation factors for all substantive variables (derived from linear (probability) models) do not indicate that testing them against each other presents a multicollinearity problem.

Table 2. Descriptive Statistics.

\begin{tabular}{lcccc}
\hline & Mean & SD & Min & Max \\
\hline Welfare chauvinism (binary) & 0.39 & 0.49 & 0 & 1 \\
\hline Welfare chauvinism (Immediately on arrival) & 0.09 & 0.28 & 0 & 1 \\
After a year, whether or not have worked & 0.10 & 0.29 & 0 & 1 \\
After worked and paid taxes at least a year & 0.42 & 0.49 & 0 & 1 \\
Once they have become a citizen/Never & 0.39 & 0.49 & 0 & 1 \\
\hline Age & 48.1 & 16.7 & 15 & 123 \\
\hline Female $\quad 0.50$ & 0.50 & 0 & 1 \\
\hline Not born in country & 0.08 & 0.27 & 0 & 1 \\
\hline Highest level of education (Ref.: ISCED 1) & 0.09 & 0.28 & 0 & 1 \\
ISCED 2 & 0.15 & 0.35 & 0 & 1 \\
ISCED 3 & 0.40 & 0.49 & 0 & 1 \\
ISCED 4 & 0.04 & 0.21 & 0 & 1 \\
ISCED 5-6 & 0.32 & 0.47 & 0 & 1 \\
\hline Main activity (Ref.: Paid Work) & 0.62 & 0.48 & 0 & 1 \\
In Education & 0.04 & 0.20 & 0 & 1 \\
Unemployed & 0.05 & 0.21 & 0 & 1 \\
Retired & 0.20 & 0.40 & 0 & 1 \\
Other & 0.08 & 0.28 & 0 & 1 \\
\hline Standardized RTI measure & -0.23 & 0.78 & -1.33 & 2.76 \\
\hline Reeling about household's income nowadays & 0.33 & 0.47 & 0 & 1 \\
Cing comfortably on present income) & 0.46 & 0.50 & 0 & 1 \\
Difficult on present income & 0.16 & 0.36 & 0 & 1 \\
Very difficult on present income & 0.05 & 0.22 & 0 & 1 \\
\hline
\end{tabular}


Table 2. Cont.

\begin{tabular}{lcccc}
\hline & Mean & SD & Min & Max \\
\hline How likely not enough money for household & 0.32 & 0.47 & 0 & 1 \\
necessities next 12 months (Ref.: Not at all likely) & 0.42 & 0.49 & 0 & 1 \\
$\quad$ Not very likely & 0.18 & 0.39 & 0 & 1 \\
$\quad$ Likely & 0.07 & 0.25 & 0 & 1 \\
$\quad$ Very likely & 0.40 & 0.49 & 0 & 1 \\
\hline How likely unemployed and looking for work & 0.28 & 0.45 & 0 & 1 \\
next 12 months (Ref.: Not at all likely) & 0.12 & 0.33 & 0 & 1 \\
$\quad$ Not very likely & 0.07 & 0.26 & 0 & 1 \\
$\quad$ Likely & 0.12 & 0.34 & 0 & 1 \\
$\quad$ Nery likely & 5.10 & 2.20 & 0 & 10 \\
\hline Left-Right Scale & 0.57 & 0.22 & 0 & 1 \\
\hline GDP per capita OECD (logged) working and not looking for work & 0.57 & 0.23 & 0 & 1 \\
Asylum Seekers per Capita (logged) & 0.41 & 0.49 & 0 & 1 \\
Year = 2016 & & & &
\end{tabular}

On the country level, we focus on two variables. First, we are interested in whether the current asylum seeking influx is relevant in the ways discussed above. This is operationalized by the number of asylum seeker applications ${ }^{3}$ per 100,000 country inhabitants ${ }^{4}$ in the respective years. GDP per capita ${ }^{5}$ serves as an indicator of economic development that is also related to a number of other factors, capturing broad socioeconomic differences between the countries. Since both variables are strongly skewed, we apply a natural log transformation to them, and we furthermore rescale them to range from 0 to 1 in order to achieve more comparable estimates. Finally, as noted above, we also enter country dummies into the models, i.e., we employ a fixed-effects analysis on the macro level by accounting for time-constant unobserved country-level heterogeneity. We drop two countries that are outliers on various dimensions of interest in this study: Ireland, because of its economic development in terms of GDP per capita figures, and Cyprus because of its distribution of the dependent variable coupled with a very high asylum per capita ratio. Other countries are missing due to data availability issues. The final analytical data set comprises 52,309 individuals, 42 country-years, and 26 countries.

\section{Results}

Figure 1 shows bivariate scatterplots depicting the relationship between the weighted percentage of welfare chauvinists (binary variable) and our macro level predictors. As we can see, both asylum seeker presence and GDP per capita appear to have some relationship to welfare chauvinism. However, some of this may also be due to compositional differences between the samples. That is, it may not be GDP per capita as a contextual factor, but really the individual economic situation that counts here. Also, since the factors we investigate here are themselves interrelated, we need to test them against each other in a multivariate model. Moreover, using a fixed effects approach we can see whether the apparent cross-sectional relationships in Figure 1 are also present in a longitudinal perspective.

3 Eurostat (2018). Asylum and first time asylum applicants by citizenship, age and sex Annual aggregated data (rounded). Available at: http:/ / appsso.eurostat.ec.europa.eu/nui/show.do?dataset=migr_asyappctza\&lang=en.

4 Eurostat (2018). Population change-Demographic balance and crude rates at national level. Available at: http://appsso. eurostat.ec.europa.eu/nui/show.do?dataset=demo_gind\&lang=en.

5 Eurostat (2017). GDP per capita in PPS. Available at: http://ec.europa.eu/eurostat $/ \mathrm{tgm} / \mathrm{table} . \mathrm{do}$ ?tab=table\&init=1\& plugin $=1 \&$ language $=$ en\&pcode=tec00114; 2016 values multiplied with scale factor for the EU 28 GDP development. 


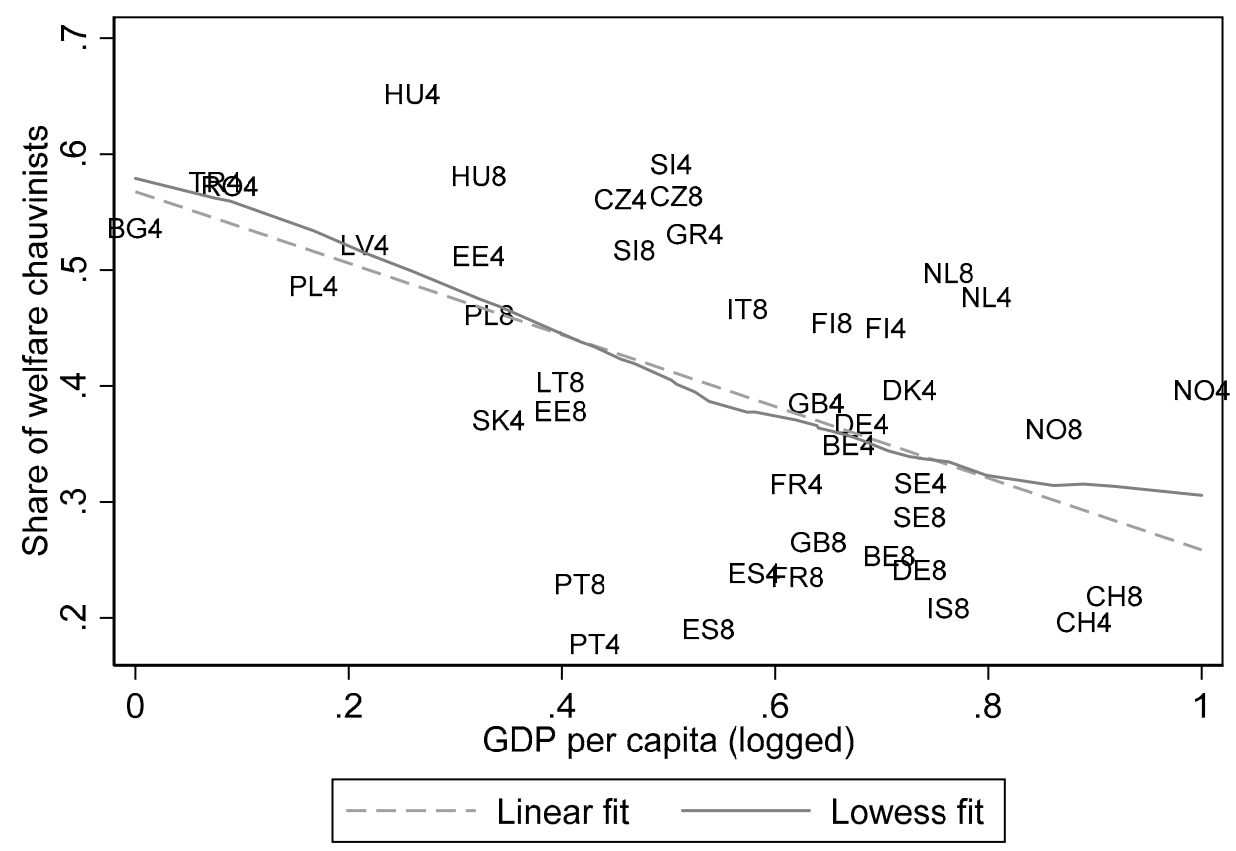

(a)

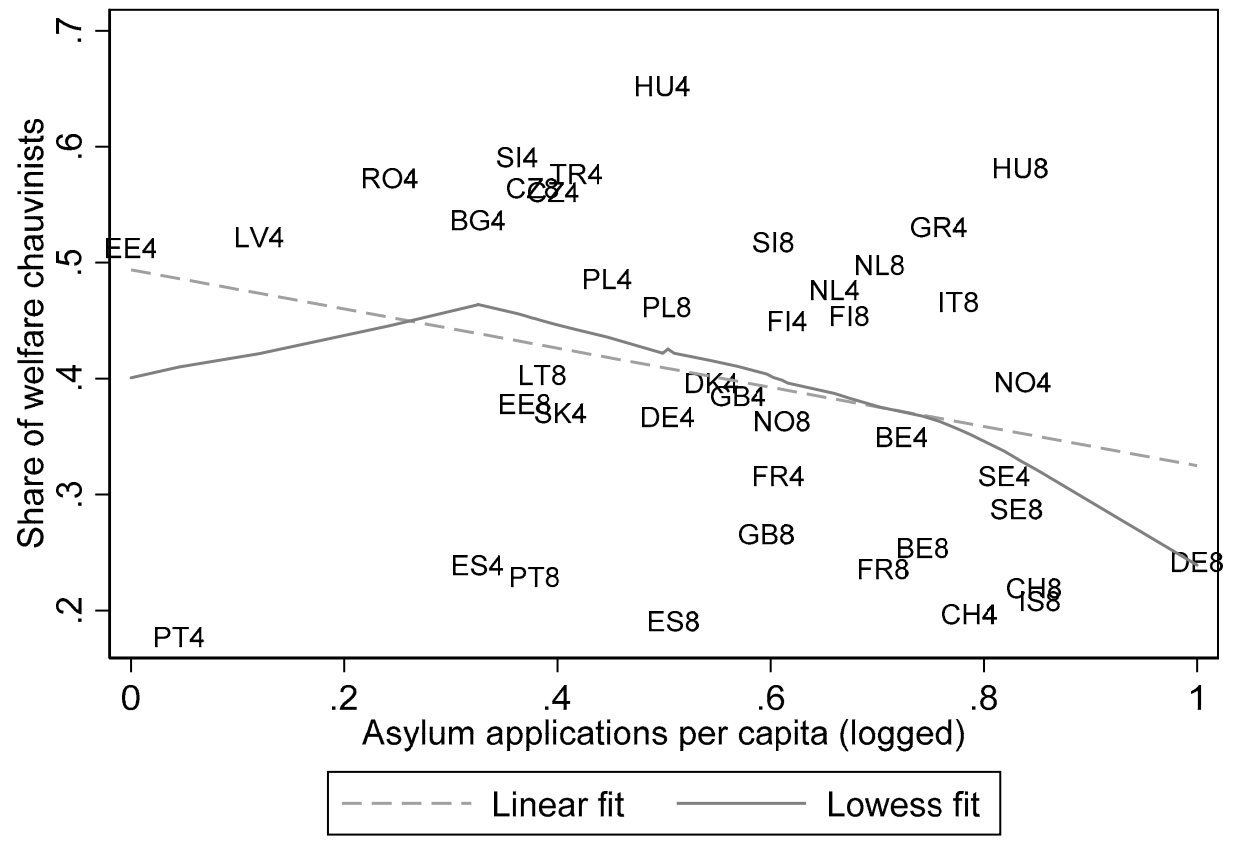

(b)

Figure 1. Macro-Level Scatterplots of Welfare Chauvinism. (a) Relationship between GDP per capita and the weighted share of welfare chauvinists; $(\mathbf{b})$ relationship between asylum seeker ratio and the weighted share of welfare chauvinists.

Table 3 displays the results for the binary logit analyses. We start with a base model plus country level effects and country dummies. This removes the time-constant country-level unobserved heterogeneity, allowing us to draw somewhat firmer causal conclusions. In the next models, we add the different facets of material deprivation one by one and simultaneously. As we want to be able to compare coefficients across models, the table displays the average marginal effects (AME) for each predictor. 
Table 3. Welfare Chauvinism, Binary Logit Models.

\begin{tabular}{|c|c|c|c|c|c|c|}
\hline & (1) & (2) & (3) & (4) & (5) & (6) \\
\hline \multicolumn{7}{|l|}{ Individual Level } \\
\hline Age & $\begin{array}{c}0.0009^{* * *} \\
(0.000)\end{array}$ & $\begin{array}{c}0.0005^{* * *} \\
(0.000)\end{array}$ & $\begin{array}{c}0.0005^{* * *} \\
(0.000)\end{array}$ & $\begin{array}{c}0.0005^{* *} \\
(0.000)\end{array}$ & $\begin{array}{c}0.0005^{* *} \\
(0.000)\end{array}$ & $\begin{array}{c}0.0005 \text { ** } \\
(0.000)\end{array}$ \\
\hline Female & $\begin{array}{c}-0.016^{* * *} \\
(0.004)\end{array}$ & $\begin{array}{c}-0.017^{* * *} \\
(0.004)\end{array}$ & $\begin{array}{c}-0.018 * * * \\
(0.004)\end{array}$ & $\begin{array}{c}-0.019 * * * \\
(0.004)\end{array}$ & $\begin{array}{c}-0.020 * * * \\
\quad(0.004)\end{array}$ & $\begin{array}{c}-0.020 \text { *** } \\
(0.004)\end{array}$ \\
\hline Not Born in country & $\begin{array}{c}-0.163^{* * * *} \\
(0.007)\end{array}$ & $\begin{array}{c}-0.163 \text { *** } \\
(0.007)\end{array}$ & $\begin{array}{c}-0.163 \text { *** } \\
(0.007)\end{array}$ & $\begin{array}{c}-0.165^{* * *} \\
(0.007)\end{array}$ & $\begin{array}{c}-0.165 \text { *** } \\
(0.007)\end{array}$ & $\begin{array}{c}-0.165^{* * *} \\
(0.007)\end{array}$ \\
\hline \multicolumn{7}{|l|}{ Highest level of education (Ref.: ISCED 1) } \\
\hline ISCED 2 & $\begin{array}{c}-0.005 \\
(0.010)\end{array}$ & $\begin{array}{l}-0.004 \\
(0.010)\end{array}$ & $\begin{array}{l}-0.004 \\
(0.010)\end{array}$ & $\begin{array}{l}-0.002 \\
(0.010)\end{array}$ & $\begin{array}{l}-0.002 \\
(0.010)\end{array}$ & $\begin{array}{l}-0.002 \\
(0.010)\end{array}$ \\
\hline ISCED 3 & $\begin{array}{c}-0.025^{* * *} \\
(0.009)\end{array}$ & $\begin{array}{c}-0.023 \text { *** } \\
(0.009)\end{array}$ & $\begin{array}{c}-0.023^{* * * *} \\
(0.009)\end{array}$ & $\begin{array}{l}-0.018^{* *} \\
(0.009)\end{array}$ & $\begin{array}{c}-0.018 \text { ** } \\
(0.009)\end{array}$ & $\begin{array}{c}-0.018^{*} \\
(0.009)\end{array}$ \\
\hline ISCED 4 & $\begin{array}{c}-0.047^{* * * *} \\
(0.013)\end{array}$ & $\begin{array}{c}-0.045^{* * * *} \\
(0.013)\end{array}$ & $\begin{array}{c}-0.045^{* * * *} \\
(0.013)\end{array}$ & $\begin{array}{c}-0.038^{* * * *} \\
(0.013)\end{array}$ & $\begin{array}{c}-0.038^{* * * *} \\
(0.013)\end{array}$ & $\begin{array}{c}-0.038^{* * * *} \\
(0.013)\end{array}$ \\
\hline ISCED 5-6 & $\begin{array}{c}-0.076^{* * *} \\
(0.009)\end{array}$ & $\begin{array}{c}-0.073^{* * *} \\
(0.009)\end{array}$ & $\begin{array}{c}-0.071^{* * * *} \\
(0.009)\end{array}$ & $\begin{array}{c}-0.063^{* * *} \\
(0.009)\end{array}$ & $\begin{array}{c}-0.061 \text { *** } \\
(0.009)\end{array}$ & $\begin{array}{c}-0.061^{* * *} \\
(0.009)\end{array}$ \\
\hline \multicolumn{7}{|l|}{ Main activity (Ref.: Paid Work) } \\
\hline In Education & & $\begin{array}{c}-0.024 \text { ** } \\
(0.011)\end{array}$ & $\begin{array}{c}-0.025 \text { ** } \\
(0.011)\end{array}$ & $\begin{array}{c}-0.027^{* *} \\
(0.011)\end{array}$ & $\begin{array}{c}-0.027^{* *} \\
(0.011)\end{array}$ & $\begin{array}{c}-0.027^{* *} \\
(0.011)\end{array}$ \\
\hline Unemployed & & $\begin{array}{c}0.004 \\
(0.010)\end{array}$ & $\begin{array}{c}0.003 \\
(0.010)\end{array}$ & $\begin{array}{l}-0.009 \\
(0.011)\end{array}$ & $\begin{array}{l}-0.010 \\
(0.011)\end{array}$ & $\begin{array}{l}-0.010 \\
(0.011)\end{array}$ \\
\hline Retired & & $\begin{array}{c}0.021 * * * \\
(0.007)\end{array}$ & $\begin{array}{c}0.020 * * * \\
(0.007)\end{array}$ & $\begin{array}{c}0.010 \\
(0.008)\end{array}$ & $\begin{array}{c}0.010 \\
(0.008)\end{array}$ & $\begin{array}{c}0.010 \\
(0.008)\end{array}$ \\
\hline Other & & $\begin{array}{c}0.017^{* * *} \\
(0.008)\end{array}$ & $\begin{array}{l}0.017^{* *} \\
(0.008)\end{array}$ & $\begin{array}{c}0.008 \\
(0.008)\end{array}$ & $\begin{array}{c}0.008 \\
(0.008)\end{array}$ & $\begin{array}{c}0.008 \\
(0.008)\end{array}$ \\
\hline Standardized RTI measure & & & $\begin{array}{l}0.005^{*} \\
(0.003)\end{array}$ & & $\begin{array}{l}0.005^{*} \\
(0.003)\end{array}$ & $\begin{array}{l}0.005 * \\
(0.003)\end{array}$ \\
\hline \multicolumn{7}{|l|}{$\begin{array}{l}\text { Feeling about household's income nowadays } \\
\text { (Ref.: Living comfortably on present income) }\end{array}$} \\
\hline Coping on present income & & & & $\begin{array}{l}0.021 * * * \\
(0.005)\end{array}$ & $\begin{array}{c}0.021 * * * \\
(0.005)\end{array}$ & $\begin{array}{c}0.021 * * * \\
(0.005)\end{array}$ \\
\hline Difficult on present income & & & & $\begin{array}{l}0.018 * * \\
(0.008)\end{array}$ & $\begin{array}{c}0.018^{* *} \\
(0.008)\end{array}$ & $\begin{array}{l}0.018 * * \\
(0.008)\end{array}$ \\
\hline Very difficult on present income & & & & $\begin{array}{l}0.029^{* *} \\
(0.012)\end{array}$ & $\begin{array}{c}0.029^{* *} \\
(0.012)\end{array}$ & $\begin{array}{l}0.029^{* *} \\
(0.012)\end{array}$ \\
\hline \multicolumn{7}{|l|}{$\begin{array}{l}\text { How likely not enough money for household } \\
\text { necessities next } 12 \text { months (Ref.: Not at all likely) }\end{array}$} \\
\hline Not very likely & & & & $\begin{array}{l}-0.002 \\
(0.005)\end{array}$ & $\begin{array}{l}-0.002 \\
(0.005)\end{array}$ & $\begin{array}{l}-0.002 \\
(0.005)\end{array}$ \\
\hline Likely & & & & $\begin{array}{l}0.013^{*} \\
(0.007)\end{array}$ & $\begin{array}{l}0.013 * \\
(0.007)\end{array}$ & $\begin{array}{l}0.013 * \\
(0.007)\end{array}$ \\
\hline Very likely & & & & $\begin{array}{c}0.050 * * * \\
(0.011)\end{array}$ & $\begin{array}{c}0.050 * * * \\
(0.011)\end{array}$ & $\begin{array}{c}0.050 * * * \\
(0.011)\end{array}$ \\
\hline \multicolumn{7}{|l|}{$\begin{array}{l}\text { How likely unemployed and looking for work next } 12 \\
\text { months (Ref.: Not at all likely) }\end{array}$} \\
\hline Not very likely & & & & $\begin{array}{l}-0.012 * * \\
(0.060)\end{array}$ & $\begin{array}{l}-0.012 * * \\
(0.060)\end{array}$ & $\begin{aligned}-0.012 * * \\
(0.060)\end{aligned}$ \\
\hline Likely & & & & $\begin{array}{r}-0.012 \\
(0.080)\end{array}$ & $\begin{array}{c}-0.013 * \\
(0.080)\end{array}$ & $\begin{array}{c}-0.013 * \\
(0.080)\end{array}$ \\
\hline Very likely & & & & $\begin{array}{l}-0.016^{*} \\
(0.010)\end{array}$ & $\begin{array}{c}-0.017^{*} \\
(0.010)\end{array}$ & $\begin{array}{c}-0.017^{*} \\
(0.010)\end{array}$ \\
\hline No longer working and not looking for work & & & & $\begin{array}{l}0.0010 \\
(0.008)\end{array}$ & $\begin{array}{l}0.0010 \\
(0.008)\end{array}$ & $\begin{array}{l}0.0010 \\
(0.008)\end{array}$ \\
\hline Left-Right Scale & $\begin{array}{c}0.015^{* * *} \\
(0.001)\end{array}$ & $\begin{array}{c}0.015^{* * *} \\
(0.001)\end{array}$ & $\begin{array}{l}0.015^{* * *} \\
(0.001)\end{array}$ & $\begin{array}{l}0.015^{* * *} \\
(0.001)\end{array}$ & $\begin{array}{c}0.015^{* * *} \\
(0.001)\end{array}$ & $\begin{array}{c}0.015^{* * *} \\
(0.001)\end{array}$ \\
\hline \multicolumn{7}{|l|}{ Country Level } \\
\hline GDP per capita OECD (logged) & $\begin{array}{l}-0.094 \\
(0.140) \\
\end{array}$ & $\begin{array}{l}-0.087 \\
(0.140)\end{array}$ & $\begin{array}{l}-0.088 \\
(0.140)\end{array}$ & $\begin{array}{l}-0.071 \\
(0.139) \\
\end{array}$ & $\begin{array}{l}-0.072 \\
(0.139) \\
\end{array}$ & \\
\hline Log Asylum Seekers per Capita & $\begin{array}{c}-0.108 \text { ** } \\
(0.051)\end{array}$ & $\begin{array}{c}-0.107 * * \\
(0.051)\end{array}$ & $\begin{array}{c}-0.108 \text { ** } \\
(0.051)\end{array}$ & $\begin{array}{c}-0.106^{* *} \\
(0.051)\end{array}$ & $\begin{array}{c}-0.106^{* *} \\
(0.051)\end{array}$ & $\begin{array}{c}-0.117 \text { ** } \\
(0.046)\end{array}$ \\
\hline Year $=2016$ & $\begin{array}{c}-0.017 * \\
(0.010)\end{array}$ & $\begin{array}{l}-0.016 \\
(0.010)\end{array}$ & $\begin{array}{c}-0.017 \text { * } \\
(0.010)\end{array}$ & $\begin{array}{l}-0.013 \\
(0.010)\end{array}$ & $\begin{array}{l}-0.015 \\
(0.010) \\
\end{array}$ & $\begin{array}{c}-0.014 \\
(0.010)\end{array}$ \\
\hline \multicolumn{7}{|l|}{ Observations } \\
\hline Country & 26 & 26 & 26 & 26 & 26 & 26 \\
\hline Country-Year & 42 & 42 & 42 & 42 & 42 & 42 \\
\hline Individual & 52,309 & 52,309 & 52,309 & 52,309 & 52,309 & 52,309 \\
\hline
\end{tabular}

*** $p<0.01,{ }^{* *} p<0.05, * p<0.1$, standard errors in parentheses. Average marginal effects. Models include country dummies. 
We first turn to objective material risks. For the labour market indicator (main activity), we see little in the way of meaningful differences between unemployed and working persons, but retired and "Other" is associated with higher levels of chauvinism, while "In Education" is associated with lower levels of welfare chauvinism. Adding the standardized RTI measure [36] in model 3, we see that, as expected, there is a positive influence of this indicator on welfare chauvinism: The more the occupation is characterized by routineness, the stronger the inclination towards welfare chauvinism.

Moving on to the perceptions and expectations of deprivation (model 4), we see that household income evaluation and the expectation to have financial problems both also lead to higher levels of welfare chauvinism. At the same time, the likelihood of becoming unemployed is associated with lower levels of chauvinism. The prospect of becoming a welfare recipient thus leads to being more open for immigrant access to welfare resources. Being retired now is statistically insignificant, which suggests that the formerly reported association is due to these perceptions and expectations.

Finally, as model 5 shows, these relationships are robust against each other. As an interim conclusion we thus can see that perceptions of deprivation are overall more meaningful, with the strongest effect flowing from the prospect of not having enough money in the next 12 months. The influence of the left-right scale is also in the expected direction, and given the 10-point scale, this effect is sizable.

For the country level the results are relatively clear: Changes in GDP per capita are not related to welfare chauvinism in our country-fixed effects model. However, the extent of asylum seekers is consistently associated with the outcome. The negative sign of the coefficient is in line with the thesis of increased refugee immigration being a specific form of migration that deserves altruistic attention, while the competition-based rationale does not gain support from our results. Model 6 shows that when GDP per capita is eliminated from the model, the result for asylum seeker presence also holds.

However, as noted above, these results need not unfold in a linear fashion across all levels of the outcome variable. In Table 4, we therefore perform a generalized ordered logit analysis for the final full model. Now, columns 1 through 3 come from a single model so that we can easily compare and interpret the raw coefficients [59]. Going from left to right, each column presents results for an increasingly restrictive preference for immigrants' welfare access as described in the table header. These models also include country fixed effects. The results overall show that the assumption of proportional odds-i.e., of effects being identical across all levels of the dependent variable-clearly is untenable for several predictors, rendering conventional ordinal logistic regression infeasible.

Table 4. Welfare Chauvinism, Generalized Ordered Logit Models.

\begin{tabular}{|c|c|c|c|}
\hline & \multicolumn{3}{|c|}{ Access to Welfare Resources after at Least... } \\
\hline & $\begin{array}{l}\text { One year Whether } \\
\text { or Not Worked }\end{array}$ & $\begin{array}{c}\text { Worked and Paid } \\
\text { Taxes at Least One } \\
\text { Year }\end{array}$ & $\begin{array}{c}\text { They Have } \\
\text { Become a Citizen }\end{array}$ \\
\hline \multicolumn{4}{|l|}{ Individual Level } \\
\hline Age & $\begin{array}{l}0.009 * * * \\
(0.002)\end{array}$ & $\begin{array}{l}0.004^{* * *} \\
(0.001)\end{array}$ & $\begin{array}{c}0.002 \\
(0.001)\end{array}$ \\
\hline Female & $\begin{array}{l}-0.060 \\
(0.039)\end{array}$ & $\begin{array}{l}-0.032 \\
(0.030)\end{array}$ & $\begin{array}{c}-0.088^{* * *} \\
(0.025)\end{array}$ \\
\hline Not Born in country & $\begin{array}{c}-0.705^{* * *} \\
(0.069)\end{array}$ & $\begin{array}{c}-0.542 * * * \\
(0.0737)\end{array}$ & $\begin{array}{c}-0.821^{* * *} \\
(0.066)\end{array}$ \\
\hline \multicolumn{4}{|c|}{ Highest level of education (Ref.: ISCED 1) } \\
\hline ISCED 2 & $\begin{array}{c}-0.105 \\
(0.070)\end{array}$ & $\begin{array}{l}0.0207 \\
(0.046)\end{array}$ & $\begin{array}{c}-0.00242 \\
(0.045)\end{array}$ \\
\hline ISCED 3 & $\begin{array}{c}-0.186^{* *} \\
(0.073)\end{array}$ & $\begin{array}{c}-0.0276 \\
(0.059)\end{array}$ & $\begin{array}{c}-0.0758 \\
(0.059)\end{array}$ \\
\hline ISCED 4 & $\begin{array}{l}-0.243^{* *} \\
(0.121)\end{array}$ & $\begin{array}{c}-0.0752 \\
(0.092)\end{array}$ & $\begin{array}{l}-0.163^{* * *} \\
(0.063)\end{array}$ \\
\hline ISCED 5-6 & $\begin{array}{c}-0.583^{* * * *} \\
(0.087)\end{array}$ & $\begin{array}{c}-0.415^{* * *} \\
(0.060)\end{array}$ & $\begin{array}{c}-0.266^{* * *} \\
(0.072)\end{array}$ \\
\hline
\end{tabular}


Table 4. Cont.

\begin{tabular}{|c|c|c|c|}
\hline & \multicolumn{3}{|c|}{ Access to Welfare Resources after at Least ... } \\
\hline & $\begin{array}{l}\text { One year Whether } \\
\text { or Not Worked }\end{array}$ & $\begin{array}{c}\text { Worked and Paid } \\
\text { Taxes at Least One } \\
\text { Year }\end{array}$ & $\begin{array}{c}\text { They Have } \\
\text { Become a Citizen }\end{array}$ \\
\hline \multicolumn{4}{|l|}{ Main activity (Ref.: Paid Work) } \\
\hline In Education & $\begin{array}{c}-0.333 * * * \\
(0.098)\end{array}$ & $\begin{array}{c}-0.377^{* * *} \\
(0.079)\end{array}$ & $\begin{array}{c}-0.122 \text { ** } \\
(0.058)\end{array}$ \\
\hline Unemployed & $\begin{array}{l}-0.022 \\
(0.089)\end{array}$ & $\begin{array}{c}-0.149^{* *} \\
(0.069)\end{array}$ & $\begin{array}{c}-0.0459 \\
(0.068)\end{array}$ \\
\hline Retired & $\begin{array}{c}0.124 \\
(0.079)\end{array}$ & $\begin{array}{l}0.0183 \\
(0.061)\end{array}$ & $\begin{array}{l}0.0520 \\
(0.039)\end{array}$ \\
\hline Other & $\begin{array}{l}0.0985 \\
(0.061)\end{array}$ & $\begin{array}{l}0.0698 \\
(0.042)\end{array}$ & $\begin{array}{l}0.0281 \\
(0.047)\end{array}$ \\
\hline Standardized RTI measure & $\begin{array}{l}0.046^{*} \\
(0.027) \\
\end{array}$ & $\begin{array}{l}0.033^{* *} \\
(0.017)\end{array}$ & $\begin{array}{l}0.027^{* *} \\
(0.013)\end{array}$ \\
\hline \multicolumn{4}{|l|}{$\begin{array}{l}\text { Feeling about household's income nowadays } \\
\text { (Ref.: Living comfortably on present income) }\end{array}$} \\
\hline Coping on present income & $\begin{array}{c}0.117^{* *} \\
(0.052)\end{array}$ & $\begin{array}{c}0.119 * * * \\
(0.041)\end{array}$ & $\begin{array}{c}0.0925^{* * *} \\
(0.0359)\end{array}$ \\
\hline Difficult on present income & $\begin{array}{l}0.143^{*} \\
(0.074)\end{array}$ & $\begin{array}{c}0.116^{* *} \\
(0.059)\end{array}$ & $\begin{array}{c}0.075 \\
(0.049)\end{array}$ \\
\hline Very difficult on present income & $\begin{array}{c}0.043 \\
(0.097)\end{array}$ & $\begin{array}{l}0.027 \\
(0.081)\end{array}$ & $\begin{array}{c}0.124 \\
(0.081)\end{array}$ \\
\hline \multicolumn{4}{|l|}{$\begin{array}{l}\text { How likely not enough money for household } \\
\text { necessities next } 12 \text { months (Ref.: Not at all likely) }\end{array}$} \\
\hline Not very likely & $\begin{array}{c}0.047 \\
(0.043)\end{array}$ & $\begin{array}{c}0.006 \\
(0.037)\end{array}$ & $\begin{array}{l}-0.007 \\
(0.023)\end{array}$ \\
\hline Likely & $\begin{array}{l}-0.018 \\
(0.067)\end{array}$ & $\begin{array}{c}0.052 \\
(0.055)\end{array}$ & $\begin{array}{c}0.067^{* *} \\
(0.031)\end{array}$ \\
\hline Very likely & $\begin{array}{l}0.0644 \\
(0.081)\end{array}$ & $\begin{array}{c}0.193 * * * \\
(0.072)\end{array}$ & $\begin{array}{c}0.224^{* * *} \\
(0.050)\end{array}$ \\
\hline \multicolumn{4}{|l|}{$\begin{array}{l}\text { How likely unemployed and looking for work next } 12 \\
\text { months (Ref.: Not at all likely) }\end{array}$} \\
\hline Not very likely & $\begin{array}{l}0.125^{* *} \\
(0.051)\end{array}$ & $\begin{array}{c}0.006 \\
(0.035)\end{array}$ & $\begin{array}{c}-0.053^{*} \\
(0.028)\end{array}$ \\
\hline Likely & $0.222 * * *$ & -0.019 & -0.063 \\
\hline Very likely & $\begin{array}{l}(0.067) \\
-0.045\end{array}$ & $\begin{array}{c}(0.043) \\
-0.045\end{array}$ & $\begin{array}{c}(0.042) \\
-0.075\end{array}$ \\
\hline very nikery & $(0.071)$ & $(0.063)$ & $(0.067)$ \\
\hline No longer working and not looking for work & $\begin{array}{c}0.120 \\
(0.091)\end{array}$ & $\begin{array}{c}0.098 \\
(0.069)\end{array}$ & $\begin{array}{c}0.039 \\
(0.062)\end{array}$ \\
\hline Left-Right Scale & $\begin{array}{c}0.177^{* * *} \\
(0.017)\end{array}$ & $\begin{array}{c}0.151^{* * *} \\
(0.015)\end{array}$ & $\begin{array}{c}0.071^{* * *} \\
(0.009)\end{array}$ \\
\hline \multicolumn{4}{|l|}{ Country Level } \\
\hline GDP per capita OECD (logged) & $\begin{array}{c}0.767 \\
(0.922)\end{array}$ & $\begin{array}{c}0.724 \\
(0.635)\end{array}$ & $\begin{array}{l}-0.266 \\
(0.617)\end{array}$ \\
\hline Log Asylum Seekers per Capita & $\begin{array}{c}-0.836^{* *} \\
(0.349)\end{array}$ & $\begin{array}{c}-0.463^{* *} \\
(0.207)\end{array}$ & $\begin{array}{c}-0.567^{* *} \\
(0.227)\end{array}$ \\
\hline Year $=2016$ & $\begin{array}{c}0.015 \\
(0.063) \\
\end{array}$ & $\begin{array}{l}-0.020 \\
(0.035) \\
\end{array}$ & $\begin{array}{l}-0.068 \\
(0.053) \\
\end{array}$ \\
\hline \multicolumn{4}{|l|}{ Country Level, excluding GDP per capita ${ }^{1}$} \\
\hline Log Asylum Seekers per Capita & $\begin{array}{c}-0.696^{* * *} \\
(0.260) \\
\end{array}$ & $\begin{array}{c}-0.330 \text { ** } \\
(0.133) \\
\end{array}$ & $\begin{array}{c}-0.616^{* * *} \\
(0.189) \\
\end{array}$ \\
\hline Observations & \multicolumn{3}{|c|}{52,309 individuals, 42 country-years, 26 countries } \\
\hline
\end{tabular}

*** $p<0.01,{ }^{* *} p<0.05, * p<0.1$, robust standard errors in parentheses. Models include country dummies. All coefficients come from a single model, except: ${ }^{1}$ : Coefficients from a second model that includes all individual level factors.

Regarding the focal individual-level factors of deprivation, the generalized ordered logit model provides important insights. For the main activity, we find that being in education is most clearly associated with a lower likelihood to restrict the welfare access of immigrants. Being unemployed leads to lower welfare chauvinism only in the form of having worked and paid taxes, which again shows the importance of the individual's role in the welfare state when forming these attitudes. For the routineness measure of the occupation there is an influence that gets smaller as the definition of 
welfare chauvinism gets more restrictive, but given the scaling of the variable of about four points, this effect is notable. Moreover, the results for the assessment of the current household income show that "Very difficult on present income" is related to neither type of welfare chauvinism. However, for the prospect of having financial problems in the future, we see the clearest and largest relationship with the most restrictive type of welfare chauvinism. The likelihood of being unemployed and looking for work is most strongly related to a more lax definition of welfare chauvinism, but again in a curvilinear fashion. Taken together with the results above, we see that deprivation overall is related to stricter welfare chauvinism, with the notable exception of the prospect of becoming unemployed.

On the country level, the results for GDP per capita and asylum seekers conform to the binary logit findings: GDP per capita is not associated with welfare chauvinism, whereas the asylum seeker influx is statistically significant and negative in all equations of the generalized ordered logit. Once we again omit the insignificant GDP per capita factor, the results underline that there are marked differences in the association of asylum seeker presence with welfare chauvinism: The coefficient for "Worked and paid taxes at least one year" is about half the size of the ones for the other two categories. This suggests that under conditions of heightened asylum seeker presence, having at least some level of quid-pro-quo (i.e., immigrant contribution) is not as undesirable as the other types of restrictions. However, there still is a pronounced negative effect also for this middling type of welfare chauvinism.

In terms of the control variables, age is significantly and positively related only to milder forms of welfare chauvinism. Gender differences are evident only for the strongest form of welfare chauvinism, with men being more likely to formulate such demands than women. Being an immigrant is consistently associated with lower levels of chauvinism. We furthermore see that the influence of education becomes less pronounced as welfare access gets more restricted. Finally, the political left and right appear most divided with regard to milder forms of welfare chauvinism, which should be especially infeasible for right-of-centre respondents. Nonetheless, in each instance, respondents identifying with the political right are more likely to restrict welfare access by immigrants.

These findings underline two important things. The first is that asylum seeker influx is across the board related to lower levels of welfare chauvinism, which implies a certain deservingness attached to this particular type of immigration. Second, a more methodological implication that we can already derive from these findings is that while we can easily see that the operationalization of welfare chauvinism applied here is ordinal, the popular support structures for these restrictions do not unfold in a monotonous relationship between these predictors and the level of welfare chauvinism desired by the respondents. This would not become visible in an ordinary ordinal logit model, and as we can see from in Table 3, turning to a binary logit can obscure some of these important findings due to information loss.

\section{Discussion}

Our primary interest on the individual level was on objective and subjective material deprivation. From the overall result pattern it appears that they have divergent implications: On the one hand, a perceived increased likelihood to fall unemployed translates to lower levels of chauvinism in the binary logit model, although this is marginally significant. This indicates that the prospect of falling into need is not related to a favour for restricting welfare access of immigrants. In contrast, the current employment status does not appear to be meaningful for welfare chauvinism, while the experience of a routine-based, and thus objectively insecure, workplace is notably associated with a higher level of chauvinism. At the same time, material hardships and future risks that are related to the household income predict higher levels of chauvinism. These relationships are much stronger, although "very difficult on present income" does not achieve statistical significance in the generalized ordered logit models. Finally, the results of the likelihood of being unemployed from the generalized ordered logit model displays a very uneven, curvilinear picture, with those in the middling categories being in favour of a lax version of welfare chauvinism, which may explain the findings from the binary logit model. Strong chauvinism ("after at least they have become a citizen") is a less attractive answer 
category for those that are not very likely to fall unemployed. The fact that there are insignificant differences between those answering "Not at all likely" and "Very likely" both in the binary and the generalized ordered logit makes these findings difficult to interpret. It may be that these two answer categories imply a certainty regarding (not) becoming unemployed, and thus of (not) becoming welfare state dependent in the near future. This certainty may inhibit any association with welfare chauvinism, which contrasts the findings for those already in unemployment. In sum, while material deprivation overall is related to stronger levels of chauvinism, the relationship between the prospect of becoming a welfare recipient in the near future exhibits a more complex and uneven relationship.

On the country level, our results support the notion that the deservingness of asylum seekers plays a role in granting social rights: Welfare chauvinism becomes less likely when there are many asylum applications in the country. This makes it clear that the sampled populations view this influx as a matter of responsibility, rather than a threat, for the welfare state. At the same time, GDP per capita is not meaningfully related to welfare chauvinism, even if we do not control for the numerous individual perceptions and deprivations in the first binary logit model. This indicates that the macro-economic developments as such across the countries investigated do not result in differences in welfare chauvinism. For these findings we made use of the longitudinal structure on the country level by accounting for time-constant unobserved heterogeneity via the inclusion of country dummies in our two-wave dataset. This lends a somewhat more credible causal interpretation of the results.

In general, comparing the results for the binary and the generalized ordered logit models, we can see that the variation in the attractiveness of these policy alternatives indeed does not necessarily match the gradient of restrictiveness with regard to many explanatory factors. The generalized ordered logit model therefore provides a more nuanced picture with regard to several factors: A "normal" ordinal logit would in some instances provide a misleading picture, which is visible on the country level, but also for several of the micro-level relationships. We therefore argue that this type of modelling provides a more realistic perspective on these processes of preference formation, but at times this may come at the cost of providing a simple and clear story.

\section{Conclusions}

Welfare chauvinism relates to a fundamental tension between immigration and the welfare state. The current migration developments in the European context and the fears voiced by some that asylum seeking is a net burden on the welfare state increase the salience of this tension. However, given the mechanisms of deservingness outlined above, it was not clear from the outset whether this migration due to humanitarian crises leads to more or to less welfare chauvinism.

Concerning the country level, we found clear evidence for the latter: The asylum seeking developments of the recent years have overall not led to higher, but rather to lower levels of welfare chauvinism. This implies a certain charitableness towards asylum seekers, in line with deservingness considerations outlined above. The fact that GDP per capita is not significant underlines that, in the period and geographic units investigated, the macro-economic development is not a driver of welfare chauvinism.

However, this does not imply that, on the individual level, economic considerations also play no role. We found clear support for the notion that subjective perceptions of deprivation are meaningful and important predictors of welfare chauvinism. Objective factors also play a role, but the extent of this is lower: While the occupational context (i.e., performing routine-based or non-routine-based tasks) plays a notable role regarding welfare chauvinism, the individual position in the welfare state (i.e., employment status) overall appears less meaningful. However, the finding that expectations of unemployment are related with a more lax form of welfare chauvinism shows that one's own prospect of becoming a welfare recipient does seem to entail a more generous view regarding welfare access for immigrants. Our differentiation of these different aspects of material deprivation thus provides a more nuanced picture with regard to the deprivation-welfare chauvinism nexus. 
Another contribution to the literature lies in exposing the differential support structures underlying each of the types of welfare chauvinism. It is evident from the results for both levels of analysis that respondents do not simply express their underlying level of welfare chauvinism when completing this survey question. They rather appear to approach the issue in a way that suggests a more complex understanding of the different implications behind these policies. This becomes visible only when methodology allows the rank distances of policy alternatives to be different than what welfare chauvinism would conceptually and what ordinary ordered logit analyses would methodologically imply. We argue that future studies would benefit from also complementing their analyses by treating the variable in this fashion, as this can uncover interesting and important divergences in the relationships investigated.

While we were able to move the literature on welfare chauvinism forward, our study has several limitations. We have looked at the influence of different individual positions in the welfare state system in a general way by depicting only the mean consequences of these positions for welfare chauvinism. However, differences in institutional welfare logics may be an important moderator for these relationships. While this was beyond the scope of the present article, future research may expand this line of inquiry by looking at the interrelation between welfare system arrangements and individual labour market position. This may also help to gain a better understanding of the uneven result pattern in the generalized ordered logit model for the relationship between unemployment expectations and welfare chauvinism. Such an investigation would also benefit from more time points spaced more closely to each other, which refers to another limitation of this study. Besides this, it would be interesting to investigate welfare chauvinism in a more detailed fashion by differentiating between different groups, as there may well be a divergent willingness to accept immigrant groups into the welfare system based on their origin or religious background. More generally, the independent variable does cover several potential policy approaches, but this is surely not exhaustive. Finally, lacking individual-level longitudinal data, we cannot be certain regarding the flow of causality between welfare chauvinism and asylum seeker influx, as low levels of welfare chauvinism may lead to a higher asylum seeker presence via creating popular support for a more permissive policymaking towards this type of immigration.

In the end, the inclusion of immigrants into welfare regimes may well stay on the political agenda as migration remains a constant but ever-changing phenomenon: The question how newcomers should be included in the welfare state does not appear separable from the current migration patterns, as our results suggest. This type of cross-group solidarity therefore is likely to stay an important aspect of social cohesion.

Author Contributions: Conceptualization, B.H., A.J., A.P.; Methodology, B.H.; Formal Analysis, B.H.; Investigation, B.H.; Writing-Original Draft Preparation, B.H., A.J., A.P.; Writing - Review \& Editing, B.H., A.J., A.P.; Visualization, B.H.

Funding: This research received no external funding.

Conflicts of Interest: The authors declare no conflict of interest.

\section{References}

1. Castles, S.; De Haas, H.; Miller, M.J. The Age of Migration: International Population Movements in the Modern World; Palgrave Macmillan: Basingstoke, UK, 2013.

2. Sainsbury, D. Welfare States and Immigrant Rights: The Politics of Inclusion and Exclusion; University Press: Oxford, UK, 2012.

3. Marshall, T.H. Citizenship and Social Class. In Sociology at the Crossroads and Other Essays; Marshall, T.H., Ed.; Heinemann: London, UK, 1963.

4. Guiraudon, V. The Marshallian Tryptich Reordered. The role of Courts and Bureaucracies in furthering Migrants' Social Rights. In Immigration and Welfare: Challenging the Borders of the Welfare State; Bommes, M., Geddes, A., Eds.; Routledge: London, UK, 2002; pp. 71-88. 
5. Banting, K.; Kymlicka, W. Is there really a retreat from multiculturalism policies? New evidence from the multiculturalism policy index. Comp. Eur. Politics 2013, 11, 577-598. [CrossRef]

6. Vink, M.P.; De Groot, G.-R. Citizenship attribution in Western Europe: International framework and domestic trends. J. Ethn. Migr. Stud. 2010, 36, 713-734. [CrossRef]

7. Koopmans, R.; Michalowski, I.; Waibel, S. Citizenship Rights for Immigrants: National Political Processes and Cross-National Convergence in Western Europe, 1980-2008. Am. J. Soc. 2012, 117, 1202-1245. [CrossRef]

8. Van Oorschot, W. Making the difference in social Europe: Deservingness perceptions among citizens of European welfare states. J. Eur. Soc. Policy 2006, 16, 23-42. [CrossRef]

9. Gorodzeisky, A.; Semyonov, M. Terms of exclusion: Public views towards admission and allocation of rights to immigrants in European countries. Ethn. Racial Stud. 2009, 32, 401-423. [CrossRef]

10. Mewes, J.; Mau, S. Unraveling working-class welfare chauvinism. In Contested Welfare States: Welfare Attitudes in Europe and Beyond; Svallfors, S., Ed.; Stanford University Press: Palo Alto, CA, USA, 2012; pp. 119-157.

11. Hjorth, F. Who benefits? Welfare chauvinism and national stereotypes. Eur. Union Politics 2016, 17, 3-24. [CrossRef]

12. Kootstra, A. Deserving and Undeserving Welfare Claimants in Britain and the Netherlands: Examining the Role of Ethnicity and Migration Status Using a Vignette Experiment. Eur. Sociol. Rev. 2016, 32, 325-338. [CrossRef]

13. Reeskens, T.; van Oorschot, W. Disentangling the 'New Liberal Dilemma': On the relation between general welfare redistribution preferences and welfare chauvinism. Int. J. Comp. Soc. 2012, 53, 120-139. [CrossRef]

14. Soysal, Y.N. Limits of Citizenship. Migrants and Postnational Membership in Europe; The University of Chicago Press: Chicago, IL, USA, 1994.

15. Bommes, M.; Geddes, A. Immigration and Welfare: Challenging the Borders of the Welfare State; Bommes, M., Geddes, A., Eds.; Routledge: London, UK, 2000.

16. Hammar, T. Democracy and the Nation State: Aliens, Denizens and Citizens in a World of International Migration; Avebury: Aldershot, UK, 1990.

17. Kitschelt, H.; McGann, A.J. The Radical Right in Western Europe: A Comparative Analysis; University of Michigan Press: Ann Arbor, MI, USA, 1995.

18. Andersen, J.G.; Bjørklund, T. Structural Changes and New Cleavages: The Progress Parties in Denmark and Norway. Acta Sociol. 1990, 33, 195-217. [CrossRef]

19. Cappelen, C.; Midtbø, T. Intra-EU Labour Migration and Support for the Norwegian Welfare State. Eur. Sociol. Rev. 2016, 32, 691-703. [CrossRef]

20. Mewes, J.; Mau, S. Globalization, Socio-Economic Status and Welfare Chauvinism: European Perspectives on Attitudes toward the Exclusion of Immigrants. Int. J. Comp. Soc. 2013, 54, 228-245. [CrossRef]

21. Heizmann, B. Symbolic Boundaries, Incorporation Policies, and Anti-Immigrant Attitudes: What Drives Exclusionary Policy Preferences? Ethn. Racial Stud. 2016, 39, 1791-1811. [CrossRef]

22. Bridges, S.; Mateut, S. Should They Stay or Should They Go? Attitudes Towards Immigration in Europe. Scott. J. Political Econ. 2014, 61, 397-429. [CrossRef]

23. Green, E.G.T. Who Can Enter? A Multilevel Analysis on Public Support for Immigration Criteria across 20 European Countries. Group Process. Intergroup Relat. 2009, 12, 41-60. [CrossRef]

24. Blalock, H.M. Toward a Theory of Minority-Group Relations; Wiley: New York, NY, USA, 1967.

25. Blumer, H. Race Prejudice as a Sense of Group Position. Pac. Sociol. Rev. 1958, 1, 3-7. [CrossRef]

26. Campbell, D.T.; LeVine, R.A. Ethnocentrism and Intergroup Relations. In Theories of Cognitive Consistency: A Sourcebook; Abelson, R.P., Aronson, E., McGuire, W.J., Newcomb, T., Rosenberg, M.J., Tannenbaum, P.H., Eds.; Rand McNally: Chicago, IL, USA, 1968; pp. 551-564.

27. Olzak, S. The Dynamics of Ethnic Competition and Conflict; Stanford University Press: Stanford, CA, USA, 1992.

28. van der Waal, J.; Achterberg, P.; Houtman, D.; de Koster, W.; Manevska, K. 'Some are more Equal than Others': Economic Egalitarianism and Welfare Chauvinism in the Netherlands. J. Eur. Soc. Policy 2010, 20, 350-363. [CrossRef]

29. Acemoglu, D.; Autor, D.H. Skills, tasks and technologies: Implications for employment and earnings. In Handbook of Labor Economics; Card, D., Ashenfelter, O., Eds.; Elsevier: New York, NY, USA, 2011; Volume 4, pp. 104-1171.

30. Autor, D.H.; Dorn, D. The growth of low-skill service jobs and the polarization of the US labor market. Am. Econ. Rev. 2013, 103, 1553-1597. [CrossRef] 
31. Autor, D.H.; Katz, L.F.; Kearney, M.S. The polarization of the U.S. labor market. Am. Econ. Rev. 2006, 96, 189-194. [CrossRef]

32. Autor, D.H.; Katz, L.F.; Kearney, M.S. Trends in U.S. wage inequality: Revising the revisionists. Rev. Econ. Stat. 2008, 90, 300-323. [CrossRef]

33. Goos, M.; Manning, A. Lousy and lovely jobs: The rising polarization of work in Britain. Rev. Econ. Stat. 2007, 89, 118-133. [CrossRef]

34. Spitz-Oener, A. Technical change, job tasks, and rising educational demands: Looking outside the wage structure. J. Lab. Econ. 2006, 24, 235-270. [CrossRef]

35. Dustmann, C.; Ludsteck, J.; Schönberg, U. Revisiting the German wage structure. Q. J. Econ. 2009, 124, 843-881. [CrossRef]

36. Goos, M.; Manning, A.; Salomons, A. Explaining job polarization: Routine-biased technological change and offshoring. Am. Econ. Rev. 2014, 104, 2509-2526. [CrossRef]

37. van der Waal, J.; De Koster, W.; Van Oorschot, W. Three Worlds of Welfare Chauvinism? How Welfare Regimes Affect Support for Distributing Welfare to Immigrants in Europe. J. Comp. Policy Anal. 2013, 15, 164-181. [CrossRef]

38. Eger, M.A.; Breznau, N. Immigration and the welfare state: A cross-regional analysis of European welfare attitudes. Int. J. Comp. Soc. 2017, 58, 440-463. [CrossRef]

39. Esping-Andersen, G. The Three Worlds of Welfare Capitalism; Princeton University Press: Princeton, NJ, USA, 1990.

40. Esping-Andersen, G. Social Foundations of Postindustrial Economies; Oxford University Press: Oxford, UK, 1999.

41. Scruggs, L.; Allan, J. Welfare-State Decommodification in 18 OECD Countries: A Replication and Revision. J. Eur. Soc. Policy 2006, 16, 55-72. [CrossRef]

42. Arts, W.; Gelissen, J. Three Worlds of Welfare Capitalism or More? A State-of-the-Art Report. J. Eur. Soc. Policy 2002, 12, 137-158. [CrossRef]

43. Heizmann, B. Social Policy and Perceived Immigrant Labor Market Competition in Europe: Is Prevention Better Than Cure? Soc. Forces 2015, 93, 1655-1685. [CrossRef]

44. Scheepers, P.; Gijsberts, M.; Coenders, M. Ethnic Exclusionism in European Countries. Public Opposition to Civil Rights for Legal Migrants as a Response to Perceived Ethnic Threat. Eur. Sociol. Rev. 2002, 18, 17-34. [CrossRef]

45. Petersen, M.B.; Slothuus, R.; Stubager, R.; Togeby, L. Deservingness versus values in public opinion on welfare: The automaticity of the deservingness heuristic. Eur. J. Political Res. 2011, 50, 24-52. [CrossRef]

46. Newman, B.J.; Hartman, T.K.; Lown, P.L.; Feldman, S. Easing the Heavy Hand: Humanitarian Concern, Empathy, and Opinion on Immigration. Br. J. Political Sci. 2013, 45, 583-607. [CrossRef]

47. Czymara, C.S.; Schmidt-Catran, A.W. Refugees Unwelcome? Changes in the Public Acceptance of Immigrants and Refugees in Germany in the Course of Europe's 'Immigration Crisis'. Eur. Sociol. Rev. 2017, 33, 735-751. [CrossRef]

48. Van Oorschot, W.; Uunk, W. Welfare Spending and the Public's Concern for Immigrants: Multilevel Evidence for Eighteen European Countries. Comp. Politics 2007, 40, 63-82. [CrossRef]

49. Pettigrew, T.F. Intergroup Contact Theory. Annu. Rev. Psychol. 1998, 49, 65-85. [CrossRef] [PubMed]

50. Pettigrew, T.F.; Tropp, L.R. A Meta-Analytic Test of Intergroup Contact Theory. J. Personal. Soc. Psychol. 2006, 90, 751-783. [CrossRef] [PubMed]

51. Allport, G. The Nature of Prejudice; Addison-Wesley: Cambridge, MA, USA, 1954.

52. Goodman, S.W. Integration Requirements for Integration's Sake? Identifying, Categorising and Comparing Civic Integration Policies. J. Ethn. Migr. Stud. 2010, 36, 753-772. [CrossRef]

53. Howard, M.M. Variation in Dual Citizenship Policies in the Countries of the EU. Int. Migr. Rev. 2005, 39, 697-720. [CrossRef]

54. Bloemraad, I.; Korteweg, A.; Yurdakul, G. Citizenship and Immigration: Multiculturalism, Assimilation, and Challenges to the Nation-State. Annu. Rev. Soc. 2008, 34, 153-179. [CrossRef]

55. Portes, A.; Curtis, J.W. Changing flags: Naturalization and its determinants among Mexican immigrants. Int. Migr. Rev. 1987, 21, 352-371. [CrossRef]

56. Snijders, T.; Bosker, R. Multilevel Analysis. An Introduction into Basic and Advanced Multilevel Modeling, 2nd ed.; Sage: London, UK; Thousand Oaks, CA, USA; New Delhi, India, 2011. 
57. Williams, R. Generalized ordered logit/partial proportional odds models for ordinal dependent variables. Stata J. 2006, 6, 58.

58. Williams, R. Understanding and interpreting generalized ordered logit models. J. Math. Soc. 2016, 40, 7-20. [CrossRef]

59. Breen, R.; Karlson, K.B.; Holm, A. Interpreting and Understanding Logits, Probits, and Other NonLinear Probability Models. Annu. Rev. Soc. 2018, 44, 39-54. [CrossRef] 